\title{
PENGARUH KECERDASAN EMOSIONAL (EQ) DAN LINGKUNGAN BELAJAR TERHADAP MOTIVASI BELAJAR SISWA SMA NEGERI 3 TANGERANG SELATAN
}

\author{
AHMAD ZAIN SARNOTO \\ Insitut PTIQ Jakarta \\ ahmadzain@ptiq.ac.id \\ SAMSU ROMLI \\ Sekolah Dasar Islam Ainul Yakin Kota Tangerang \\ zamromel@gmail.com
}

\begin{abstract}
ABSTRAK
Penelitian ini bertujuan untuk mengetahui dan menguji data-data empirik terkait dengan Kecerdasan Emosional dan Lingkungan Belajar terhadap Motivasi Belajar siswa secara parsial maupun simultan. Dalam penelitian ini penulis menggunakan metode survey dengan teknik korelasional dan analisa regresi sederhana dan ganda. Sampel diambil dari populasi sebanyak 144 dari total 224 populasi siswa kelas XI SMA Negeri 3 Tangerang Selatan. Teknik pengumpulan data menggunakan angket, observasi, dan studi dokumenter. Teknik analisa data yang digunakan adalah model Deskriptif, koefisien korelasi, analisa regresi sederhana dan regresi ganda yang dijabarkan secara deskriptif. Hasil penelitian ini menunjukkan bahwa: Pertama; Terdapat pengaruh positif dan signifikan Kecerdasan Emosional terhadap Motivasi Belajar siswa kelas XI di SMA Negeri 3 Tangerang Selatan. Hal ini dibuktikan dengan hasil nilai koefisien korelasi sebesar 0,248 (korelasi rendah) dan koefisien determinasi R2 sebesar 0,061 artinya besarnya pengaruh adalah 6,1\%. Persamaan regresi sederhananya adalah $\hat{Y}=95,29+0,176 X 1$, yang berarti bahwa setiap peningkatan satu unit skor kecerdasan emosional akan mempengaruhi peningkatan skor motivasi belajar siswa senilai 0,176. Kedua; Terdapat pengaruh positif dan signifikan Lingkungan Belajar terhadap Motivasi Belajar siswa kelas XI di SMA Negeri 3 Tangerang Selatan. Hal ini dibuktikan dengan hasil nilai koefisien korelasi sebesar 0,321 (korelasi sedang) dan koefisien determinasi R2 sebesar 0,103 artinya besarnya pengaruh adalah 10,3\%. Persamaan regresi sederhananya adalah $\hat{Y}=91,031+0,200 X 2$, yang berarti bahwa setiap peningkatan satu unit skor lingkungan belajar akan mempengaruhi peningkatan skor motivasi belajar siswa senilai 0,200. Ketiga; Terdapat pengaruh positif dan signifikan Kecerdasan Emosional dan Lingkungan Belajar secara simultan terhadap Motivasi Belajar siswa kelas XI di SMA Negeri 3 Tangerang Selatan. Hal ini terlihat dari hasil nilai koefisien korelasi sebesar 0,408 (korelasi sedang) dan koefisien determinasi $\mathrm{R}^{2}$ sebesar 0,166 artinya besarnya pengaruh adalah $16,6 \%$. Persamaan regresi gandanya adalah $\hat{Y}=69,786+0,178 X_{1}+0,202 X_{2}$, yang berarti bahwa setiap peningkatan satu unit skor kecerdasan emosional dan lingkungan belajar secara simultan akan mempengaruhi peningkatan skor motivasi belajar siswa senilai 0,38.
\end{abstract}

Kata kunci: Kecerdasan Emosional, Lingkungan Belajar dan Motivasi Belajar 


\begin{abstract}
This study aims to determine and test empirical data related to Emotional Intelligence and Learning Environment on Student Learning Motivation partially or simultaneously. In this study the authors used a survey method with correlational techniques and simple and multiple regression analysis. Samples were taken from a population of 144 out of a total of 224 population of class XI students of SMA Negeri 3 Tangerang Selatan. Data collection techniques using questionnaires, observation, and documentary studies. The data analysis technique used is descriptive model, correlation coefficient, simple regression analysis and multiple regression which are described descriptively. The results of this study indicate that: First; There is a positive and significant influence on Emotional Intelligence on Learning Motivation of students of class XI at SMA Negeri 3 Tangerang Selatan. This is evidenced by the results of the correlation coefficient of 0.248 (low correlation) and the coefficient of determination R2 of 0.061 meaning that the magnitude of influence is $6.1 \%$. The simple regression equation is $\hat{Y}=95.29+0.176 \mathrm{X} 1$, which means that each increase in one unit of emotional intelligence scores will affect an increase in student learning motivation scores of 0.176. Second; There is a positive and significant influence of the Learning Environment on the Learning Motivation of Grade XI students at SMA Negeri 3 Tangerang Selatan. This is evidenced by the results of the correlation coefficient of 0.321 (moderate correlation) and the coefficient of determination R2 of 0.103 meaning the magnitude of influence is $10.3 \%$. The simple regression equation is $\hat{Y}=91.031+0.200 X 2$, which means that each increase in one unit of the learning environment score will affect the increase in student learning motivation scores of 0.200 . Third; There is a positive and significant influence of Emotional Intelligence and Learning Environment simultaneously on the Learning Motivation of Grade XI students at SMA Negeri 3 Tangerang Selatan. This can be seen from the results of the correlation coefficient of 0.408 (moderate correlation) and the coefficient of determination R2 of 0.166 meaning the magnitude of influence is $16.6 \%$. The double regression equation is $\hat{Y}=69.786+$ $0.178 \times 1+0.202 X 2$, which means that each increase in one unit of emotional intelligence scores and the learning environment will simultaneously influence an increase in student learning motivation scores of 0.38 .
\end{abstract}

Keywords: Emotional Intelligence, Learning Environment and Learning Motivation 


\section{A. PENDAHULUAN}

Selama ini sebagian masyarakat masih meyakini bahwa untuk meraih kesuksesan yang tinggi diperlukan Kecerdasan Intelektual (IQ) yang tinggi pula. Namun, menurut hasil penelitian terbaru di bidang psikologi membuktikan bahwa IQ bukanlah satu-satunya faktor yang mempengaruhi kesuksesan seseorang, melainkan ada banyak faktor lain, salah satunya adalah kecerdasan emosional (EQ). Sebagai contoh ada peserta didik yang memiliki IQ tinggi tetapi memiliki prestasi yang rendah, tetapi ada peserta didik yang ber-IQ rendah, dapat mencapai hasil akademik yang tinggi. Bahkan, seringkali ada siswa dalam proses belajar mengajar di sekolah yang tidak dapat mencapai hasil akademis yang setara dengan IQ mereka.

IQ atau Intelligence Quotient sebenarnya hanya menyumbang 20\% bagi kesuksesan seseorang, sedangkan $80 \%$ lainnya adalah sumbangan faktor-faktor kemampuan lain, ${ }^{1}$ diantaranya adalah EQ atau Emotional Quotient yakni kemampuan memotivasi diri sendiri, mengatasi frustasi, mengontrol desakan hati, mengatur suasana hati (mood), berempati serta kemampuan bekerja sama. Dalam proses belajar siswa, kedua inteligensi itu sangat diperlukan. IQ tidak dapat berfungsi dengan baik tanpa partisipasi penghayatan emosional terhadap mata pelajaran yang disampaikan di sekolah. Namun biasanya kedua inteligensi itu saling melengkapi. Keseimbangan antara IQ dan EQ merupakan kunci keberhasilan belajar siswa di sekolah. ${ }^{2}$ Penyeimbangan Kecerdasan Emosional (EQ) dapat mempengaruhi sumber daya manusia dan pola pikir masyarakat Indonesia terutama para pendidik/guru. Guru seharusnya lebih mengutamakan kecerdasan emosional dalam melihat perkembangan siswa. Dengan kecerdasan Emosional yang dimiliki siswa dapat berpengaruh dalam pengembangan mutu pendidikan di sekolah negeri maupun swasta.

Kesempatan pertama untuk membentuk unsur-unsur kecerdasan emosional terletak pada tahun-tahun paling awal perkembangan seseorang, meskipun kemampuan ini terus terbentuk sepanjang masa sekolah. Sebuah laporan dari National Center for Clinical Infant Programs menyatakan bahwa keberhasilan di sekolah bukan diramalkan oleh kumpulan fakta seorang siswa atau kemampuan dirinya untuk membaca, melainkan oleh ukuran-ukuran emosional dan sosial: yakni pada diri sendiri dan mempunyai minat, tahu pola perilaku yang diharapkan orang lain dan bagaimana mengendalikan dorongan hati untuk berbuat nakal, mampu menunggu, mengikuti petunjuk dan mengacu pada guru untuk mencari bantuan, serta mengungkapkan kebutuhan-kebutuhan saat bergaul dengan siswa lain. ${ }^{3}$ Hampir semua siswa yang prestasi sekolahnya

${ }^{1}$ Daniel Goleman. Kecerdasan Emosional (terjemahan oleh T. Hermaya). Jakarta: PT. Gramedia Pustaka Utama, cetakan ke-24, 2018, h.42

3Daniel Goleman. Kecerdasaan..., h.34

${ }^{3}$ Daniel Goleman. Kecerdasan..., h.273 
buruk, menurut laporan tersebut, tidak memiliki satu atau lebih unsur-unsur kecerdasan emosional ini.

Individu yang memiliki tingkat kecerdasan emosional yang lebih baik, dapat menjadi lebih terampil dalam menenangkan dirinya dengan cepat, jarang tertular penyakit, lebih terampil dalam memusatkan perhatian, lebih baik dalam berhubungan dengan orang lain, lebih cakap dalam memahami orang lain dan untuk kerja akademis di sekolah lebih baik. ${ }^{4}$ Kecerdasan emosional mencakup kemampuan yang berbeda, tetapi mempengaruhi kecerdasan akademik (academic intellegence). Orang tidak akan mampu menggunakan kemampuan kognitif mereka sesuai dengan potensi yang maksimum tanpa memiliki kecerdasan emosional ${ }^{5}$. Kecerdasan emosional memiliki peran yang sangat penting untuk mencapai kesuksesan di sekolah maupun dalam berkomunikasi di lingkungan masyarakat. Kecerdaasan emosional mencakup kemampuan yang berbeda-beda, tetapi saling melengkapi dengan kecerdasan akademik (academic intellegence). Menurut Goleman, individu yang memiliki kecerdasan emosional rendah maka cenderung akan terlihat sebagai orang yang keras kepala, sulit bergaul, mudah frustrasi, tidak mudah percaya kepada orang lain, tidak peka dengan kondisi lingkungan dan cenderung putus asa bila mengalami stress. Kondisi sebaliknya, dialami oleh orang-orang yang memiliki taraf IQ rata-rata namun memiliki kecerdasan emosional yang tinggi. ${ }^{6}$

Kecerdasan emosional merupakan salah satu faktor penting yang seharusnya dimiliki oleh siswa yang memiliki kebutuhan untuk meraih prestasi belajar yang lebih baik di sekolah, karena kecerdasan emosional sangat berpengaruh terhadap hasil belajar siswa. Tidak hanya itu terdapat juga salah satu penunjang untuk mendapatkan hasil belajar yang baik yaitu dengan tersedianya lingkungan belajar yang kondusif.

Lingkungan belajar adalah salah satu komponen penting yang terdapat dalam proses pembelajaran. Lingkungan belajar seharusnya merupakan bagian yang mendapat perhatian guru dalam kegiatan pembelajaran. Akan tetapi kurang bervariasi dan belum optimalnya media pembelajaran yang digunakan menyebabkan kurangnya minat siswa untuk belajar. Hal ini sangat disayangkan, karena bertolak belakang dengan tujuan media pembelajaran, yakni sebagai alat bantu belajar yang berguna untuk mengefektifkan proses pembelajaran. Lingkungan sekolah merupakan salah satu tempat atau wahana yang paling umum digunakan sebagai media pembelajaran dalam proses belajar mengajar di Indonesia. Dalam pembelajaran dibutuhkan keaktifan siswa sebagai dasar untuk

${ }^{4}$ John Gottman. Kiat-kiat Membesarkan Anak yang Memiliki Kecerdasan Emosional (terjemahan). Jakarta: PT Gramedia Pustaka Utama, 2001, h.17

${ }^{5}$ Alex Tri Kantjono Widodo. Kecerdasan Emosi untuk Mencapai Puncak Prestasi. Jakarta: PT. Gramedia Pustaka Utama. Terjemahan: Working With Emotional Intelligence, Goleman, D, 1999, h.512

${ }^{6}$ Daniel Goleman. Kecerdasan..., h.52 
pengembangan materi lebih lanjut, hal ini sangat dipengaruhi oleh faktor-faktor metode pembelajaran yang digunakan.

Pembelajaran yang pasif akan menghambat kreatifitas pola pikir siswa dalam memahami suatu materi. Oleh karena itu, dalam proses pembelajaran siswa dituntut untuk benar-benar aktif, sehingga daya ingat siswa terhadap apa yang dipelajari akan lebih baik. Lingkungan memiliki kemampuan untuk memotivasi proses interaksi guru dengan siswa agar lebih optimal. Lingkungan belajar yang nyaman dalam proses pembelajaran akan membantu memotivasi belajar siswa dalam memunculkan rasa ingin tahu, berinteraksi sesuai penjelasan guru, juga membantu mengkonkretkan sesuatu yang abstrak. Motivasi merupakan salah satu penggerak siswa untuk belajar. Seorang siswa yang memiliki motivasi belajar yang tinggi cenderung giat belajar sehingga mempengaruhi keberhasilan dalam proses belajar maupun keberhasilan dalam hidupnya. Menurut Dimyati dan Mudjiono motivasi belajar adalah dorongan mental yang menggerakkan dan mengarahkan perilaku manusia untuk belajar. ${ }^{7}$ Di dalam motivasi terdapat tiga komponen yang utama yaitu kebutuhan, dorongan dan tujuan. Sejalan dengan hal tersebut, Iskandar ${ }^{8}$ menjelaskan bahwa motivasi mempunyai peran dalam pembelajaran, yaitu 1)sebagai pendorong kegiatan pembelajaran, memperjelas tujuan pembelajaran, (2) menyeleksi arah perbuatan siswa untuk mendapat hasil yang baik dalam belajar.

Hakikat motivasi belajar adalah dorongan internal dan eksternal pada siswa-siswa yang sedang belajar untuk mengadakan perubahan tingkah laku. Hal ini mempunyai peranan besar dalam keberhasilan seseorang dalam belajar. Dengan demikian motivasi belajar merupakan salah satu faktor yang mempengaruhi prestasi belajar siswa. ${ }^{9}$ Tingginya motivasi belajar berhubungan dengan tingginya prestasi belajar. Motivasi yang kuat dalam diri siswa akan meningkatkan minat, kemauan dan semangat yang tinggi dalam belajar, karena antara motivasi dan semangat belajar mempunyai hubungan yang erat. Sebagaimana yang dikatakan oleh Sardiman A.M dalam bukunya Interaksi dan Motivasi Belajar Mengajar bahwa: "Dalam kegiatan belajar, maka motivasi menimbulkan kegiatan belajar, menjamin kelangsungan dari kegiatan belajar, sehingga tujuan yang dikehendaki oleh subjek belajar itu dapat tercapai."10

Motivasi dan belajar adalah dua kata yang dirangkai yang saling mempengaruhi satu sama lain dalam hal perubahan tingkah laku seseorang yang relatif permanen akibat dari praktik atau penguatan (reinforced) untuk mencapai tujuan tertentu. Suatu cita-cita yang telah dicanangkan oleh sesorang siswa tidak akan pernah tercapai apabila dalam kegiatan belajar tidak disertai

${ }^{7}$ Nursalam dan Ferry Efendi. Pendidikan dalam Keperawatan. Jakarta: Salemba Medika, 2008, h.26.

${ }^{8}$ Iskandar. Metodologi Penelitian Kualitatif. Jakarta: Gaung Persada Press, 2009, h.38

${ }^{9}$ Hamzah B Uno. Teori Motivasi dan Pengukurannya. Jakarta: PT Bumi Aksara, 2011, h.23

${ }^{10}$ Sardiman A.M. Interaksi dan Motivasi Belajar Mengajar. Jakarta: Rajawali, 2018, h.84 
motivasi belajar yang tinggi. Motivasi merupakan salah satu aspek psikologis yang ada pada diri seseorang untuk bergairah melakukan kegiatan belajar. Menurut Egsenck dalam Slameto ${ }^{11}$ motivasi merupakan suatu proses yang menentukan tingkatan kegiatan, intensitas, konsisten, serta arah umum dari tingkah laku manusia. Seseorang termotivasi atau terdorong untuk melakukan sesuatu karena adanya tujuan atau kebutuhan yang hendak dicapai. Di dalam motivasi terdapat tiga komponen utama yaitu kebutuhan, dorongan dan tujuan ${ }^{12 .}$ Kebutuhan terjadi ketika seseorang merasakan ketidakseimbangan antara apa yang dimiliki dengan apa yang diharapkan. Dorongan adalah suatu kekuatan mental untuk melakukan kegiatan dalam memenuhi harapan atau tujuan. Dorongan yang beorientasi pada tujuan tersebut merupakan inti dari motivasi. Sedangkan tujuan merupakan hal yang ingin dicapai seseorang sehingga mengarahkan perilaku belajar.

Siswa dapat melakukan kegiatan belajar disebabkan adanya dorongan berupa kekuatan mental yang ditenggarai sebagai "motivasi belajar". Kekuatan mental itu bisa berupa keinginan yang kuat, perhatian, kemauan dan cita-cita. Agar lebih jelas, berikut disajikan pendapat beberapa ahli pendidikan terkait batasan arti motivasi belajar, diantaranya:

a. Dimyati dan Mudjiono mendefinisikan motivasi belajar sebagai dorongan mental yang menggerakkan dan mengarahkan perilaku manusia untuk belajar ${ }^{13}$.

b. Kemudian menurut Clayton Alderfer dalam H. Nashar ${ }^{14}$, motivasi belajar adalah suatu dorongan internal dan eksternal yang menyebabkan seseorang (individu) untuk bertindak atau berbuat mencapai tujuan, sehingga perubahan tingkah laku pada diri siswa diharapkan terjadi.

c. Menurut Abraham Maslow dalam H. Nashar ${ }^{15}$, Motivasi belajar juga merupakan kebutuhan untuk mengembangkan kemampuan diri secara optimal, sehingga mampu berbuat yang lebih baik, berprestasi dan kreatif.

d. Menurut Sardiman, ${ }^{16}$ motivasi belajar adalah keseluruhan daya penggerak dalam diri siswa yang menimbulkan kegiatan belajar, yang menjamin kelangsungan dari kegiatan belajar dan memberikan arah pada kegiatan belajar, sehingga tujuan yang dikehendaki oleh subyek belajar itu dapat tercapai.

${ }^{11}$ Slameto. Belajar Dan Faktor-Faktor Yang Mempengaruhinya. Cet.6, Jakarta: PT Rineka Cipta, 2015, h.170

${ }^{12}$ Husamah, dkk. Belajar dan Pembelajaran. Malang: UMM Press, 2018, h.21

${ }^{13}$ Nursalam \& Efendi. Pendidikan Dalam Keperawatan. Jakarta: Salemba Medika. 2008, h. 27

${ }^{14}$ H.Nashar. Peranan Motivasi dan Kemampuan awal dalam kegiatan Pembelajaran. Jakarta: Delia Press, 2004, h.42

${ }^{15}$ H. Nashar. Peranan Motivasi dan....h, 42

${ }^{16}$ Sardiman A.M. Integrasi dan Motivasi Belajar. Jakarta: PT Raja Grafindo Persada, 2006, h.75. 
e. Winkel dalam Husamah ${ }^{17}$ berpendapat bahwa motivasi belajar adalah keseluruhan daya penggerak di dalam diri siswa untuk menimbulkan kegiatan belajar dan memberikan arah pada kegiatan belajar itu sehingga tujuan yang dikehendaki tercapai.

Dari uraian di atas dapat dipahami bahwa motivasi belajar dapat dikatakan sebagai kekuatan pendorong, baik dari dalam maupun dari luar siswa yang menjamin kesinambungan dan memberikan ke arah kegiatan belajar, sehingga tujuan yang dikehendaki dapat tercapai. Jadi motivasi belajar adalah kondisi psikologis yang mendorong siswa untuk belajar dengan senang dan belajar secara sungguh-sungguh, yang pada gilirannya akan terbentuk cara belajar siswa yang sistematis, penuh konsentrasi dan dapat menyeleksi kegiatankagiatannya.

Dalam kegiatan belajar, keberadaan motivasi adalah kekuatan utama sebagai pendorong dalam diri seorang pelajar karena dapat memicu tindakan belajar, menjamin kelangsungan tindakan belajar dan memberikan arah sehingga dapat mencapai tujuan yang diinginkan siswa. Hakikat motivasi belajar sebenarnya merupakan dorongan internal dan eksternal pada seseorang yang sedang melakukan aktivitas belajar yang bertujuan untuk mengadakan perubahan tingkah laku dengan beberapa indikator yang mendukung. Menurut Hamzah B. Uno ${ }^{18}$, indikator motivasi belajar dapat dikatakan sebagi adanya hasrat dan keinginan untuk berhasil, adanya dorongan dan kebutuhan dalam belajar, adanya harapan dan cita-cita masa depan, adanya penghargaan dalam belajar, adanya kegiatan yang menarik dalam belajar, dan adanya lingkungan belajar yang kondusif, sehingga memungkinkan seseorang dapat belajar dengan baik.

Ciri-ciri seseorang yang memiliki motivasi positif yang dipaparkan oleh Worrel dan Stilwell dalam Nursalam dan Efendi ${ }^{62}$ adalah; menunjukkan minat, mempunyai perhatian dan berkeinginan untuk ikut serta dalam belajar dan pembelajaran, berusaha keras dan memberikan porsi waktu yang lebih kepada usaha tersebut, dan terus bekerja/belajar hingga tugas dapat terselesaikan. Penguatan motivasi-motivasi belajar tersebut berada ditangan para guru pendidik dan anggota masyarakat yang lain. Guru sebagai pendidik bertugas memperkuat motivasi belajar selama minimum 9 tahun pada usia wajib belajar. Orang tua bertugas memperkuat motivasi belajar sepanjang hayat. Al-Qur'an memotivasi dan mengarahkan setiap manusia untuk belajar, diantaranya tertera dalam surat al An'am 160,

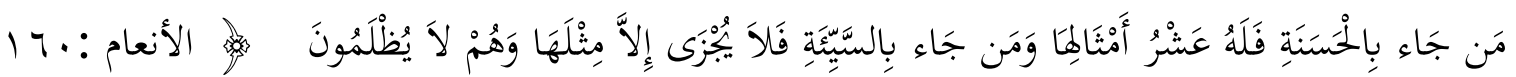

${ }^{17}$ Husamah, dkk. Belajar..., h.21

${ }^{18 H a m z a h}$ B Uno. Teori Motivasi..., h. 23 
"Barang siapa membawa amal yang baik maka baginya (pahala) sepuluh kali lipat amalnya; dan barang siapa yang membawa perbuatan yang jahat maka dia tidak diberi pembalasan melainkan seimbang dengan kejahatannya, sedang mereka sedikit pun tidak dianiaya /dirugikan." (al-An'am:160)

Siapa yang membawa amal yang baik, yakni zikir laa ilaaha illallaah (tidak ada tuhan selain Allah) maka baginya pahala sepuluh kali lipat amalnya, balasan pahalanya adalah sepuluh kali kebaikan dan siapa membawa perbuatan yang jahat, maka dia tidak diberi pembalasan melainkan seimbang dengan kejahatannya, balasannya yang setimpal (sedang mereka sedikit pun tidak dianiaya atau dirugikan) ataupun dikurangi sesuatu dari pembalasan yang sebenarnya. ${ }^{19}$ Barang siapa melakukan perbuatan baik, akan memperoleh sepuluh kali lipat, sebagai karunia dan pemberian Allah. Barangsiapa melakukan perbuatan tidak baik hanya akan disiksa seberat dosanya, atas dasar keadilan Allah menambah hukuman. ${ }^{20}$

Ayat di atas merupakan penjelasan kepada kita bahwa perbuatan baik (amal sholeh) jika dilakukan akan berdampak kepada diri kita sendiri dan selalu diberikan balasan yang besar. Sehingga ayat ini dapat memacu seseorang untuk lebih terdorong (termotivasi) untuk melakukan perbuatan baik yang sebanyakbanyaknya. Demikian juga seorang pelajar, yang memahami ayat ini akan senantiasa melakukan kegiatan belajar dengan gigih dan tekun, karena efek (feedback) yang akan ditimbulkan dari kegiatan belajar terutama terhadap diri pribadinya. Motivasi belajar meliputi dua komponen yaitu komponen dalam (inner component) dan komponen luar (outer component). Komponen dalam adalah perubahan di dalam diri seseorang, keadaan merasa tidak puas, dan ketegangan psikologis. Komponen luar meliputi apa yang ingin diinginkan seseorang, tujuan yang menjadi arah tujuannya. ${ }^{21}$

Bila ditelisik dari sisi motivasi, sesungguhnya kita dapat mengetahui bahwa perilaku seorang pelajar dalam melakukan kegiatan belajar dapat dipahami sangat dipengaruhi oleh motivasi belajarnya. Sehingga bisa dikatakan bahwa motivasi belajar sangat berperan dalam meningkatkan ketekunan, kegigihan dan kedisiplinannya dalam belajar. Salah satu pendapat tentang peranan motivasi belajar dikemukakan oleh Hamzah Uno ${ }^{22}$, yang menyebutkan

${ }^{19}$ Jalaluddin \& Jalaluddin As-Suyuthi. Tafsir Jalalain. Terjemahan Bahrun Abu Bakar, Jakarta: Sinar Baru Algensindo, 2008, h.

${ }^{20}$ Quraish Shihab. Tafsīr Al-Mishbah, Pesan, Kesan dan Keserasian al-Qur'ān. Vol.3, Jakarta: Lentera Hati, 2002, h.76

${ }^{21}$ Dimyati dan Mudjiono. Belajar dan Pembelajaran. Jakarta: PT Rineke Cipta, 2006, h.26

${ }^{22}$ Hamzah B Uno. Teori Motivasi..., h.27-28 
bahwa peran penting dari motivasi belajar dan pembelajaran, adalah; a)Menentukan hal-hal yang dapat dijadikan penguat belajar, b)Memperjelas tujuan belajar yang hendak dicapai, dan c)Menentukan ragam kendali terhadap rangsangan dan ketekunan belajar.

Motivasi dapat menjadi penguatan belajar apabila seseorang yang belajar dihadapkan pada suatu masalah yang memerlukan pemecahan, dan hanya dapat dipecahkan berkat bantuan hal-hal yang pernah dilaluinya. Salah satu contohnya bila seorang siswa akan memcahkan materi matematika dengan bantuan tabel logaritma, sehingga ia akan berusaha untuk memperolehnya. Upaya untuk mendapatkan buku tabel logaritma itu merupakan peran motivasi yang dapat menimbulkan penguatan belajar. Upaya guru dapat menjadi faktor penguat peran motivasi bagi siswa yaitu dengan mengaitkan isi pelajaran dengan berbagi perangkat yang berada dekat dengan siswa di lingkungan sekitarnya.

Peran motivasi dalam memperjelas tujuan belajar erat kaitannya dengan kemaknaan belajar. Siswa akan tertarik dengan belajar sesuatu apabila ia telah mengetahui arti dan manfaatnya terutama terhadap dirinya sendiri. Siswa yang telah termotivasi untuk belajar sesuatu akan terus belajar dan berusaha dengan baik dan tekun agar memperoleh hasil yang diharapkan. Hal tersebut jelas memperlihatkan bahwa peranan motivasi belajar menyebabkan siswa menjadi tekun belajar. Sebaliknya siswa yang tidak memiliki motivasi belajar akan malas dan tidak akan bertahan lama. Ia akan beralih kapada kegiatan lain yang membuatnya lebih bergairah dan bukan kegiatan belajar. Ini menandakan bahwa motivasi belajar mempunyai peran yang sangat dominan dalam hal ketahanan dan ketekunan belajar.

Sementara itu Oemar Hamalik ${ }^{23}$ mengemukakan tiga peran motivasi belajar yang dapat jelaskan, yaitu; a) Mendorong timbulnya kelakuan atau sesuatu perbuatan dalam hal ini perbuatan seperti belajar, b)Motivasi berfungsi sebagai pengarah, yang artinya menggerakkan perbuatan ke arah pencapaian tujuan yang di inginkan, dan c)Motivasi berfungsi penggerak Motivasi ini berfungsi sebagai mesin, besar kecilnya motivasi akan menentukan cepat atau lambatnya suatu pekerjaan atau perbuatan. Jadi dapat dipahami bahwa peranan motivasi belajar secara umum adalah sebagai daya penggerak yang mendorong seseorang untuk melakukan kegiatan belajar untuk mencapai tujuan tertentu yang diharapkan seperti nilai yang baik, kepercayaan diri yang meningkat, kepuasan, penghargaan dari lingkungan sekitar, dan sebagainya.

Suatu perbuatan manusia atau perilaku tentu saja dipengaruhi oleh faktor-faktor lain baik yang berasal dari dalam diri sendiri (internal factor) maupun lingkungannya (external factor). Seringkali beberapa faktor saling 
mempengaruhi dalam membentuk perilaku individu meskipun pengaruhnya menjadi lebih dominan dibandingkan dengan yang lain.

Demikian halnya dengan motivasi belajar akan sangat dipengaruhi oleh diri dan lingkungannya baik lingkungan keluarga maupun lingkungan sosial seorang pelajar. Pada umumnya, motif dasar yang bersifat pribadi muncul dalam tindakan individu setelah "dibentuk" oleh pengaruh lingkungan ${ }^{24}$. Misalnya keinginan untuk belajar dengan baik, dapat diubah atau diperbaiki dan dikembangkan melalui pengaruh lingkungan yaitu dengan melakukan latihanlatihan. Menurut Dimyati dan Mudjiono ${ }^{25}$ ada beberapa faktor yang mempengaruhi motivasi belajar, yaitu:

a. Cita-cita atau aspirasi siswa

Cita-cita dapat berlangsung dalam waktu sangat lama, bahkan sepanjang hayat. Cita-cita siswa untuk "menjadi seseorang" akan memperkuat semangat belajar dan mengarahkan pelaku belajar. Cita-cita akan memperkuat motivasi belajar intrinsik maupun ektrinsik sebab tercapainya suatu cita-cita akan mewujudkan aktualisasi diri.

Sedangkan menurut Suciati dan Prasetya ${ }^{26}$, cita-cita yang bersumber dalam diri seseorang mendorong seseorang berbuat lebih banyak yang diindikasikan dengan: sifat ingin tahu dan ingin menyelidiki dunia yang lebih luas, memiliki kreativitas tinggi, memiliki keinginan untuk memperbaiki kegagalan, berusaha untuk bekerja sama dengan teman dan guru, berusaha menguasai seluruh mata pelajaran yang diberikan, dan memiliki pandangan bahwa semua mata pelajaran penting.

b. Kemampuan Belajar

Dalam belajar dibutuhkan berbagai kemampuan. Kemampuan ini meliputi beberapa aspek psikis yang terdapat dalam diri siswa. Misalnya pengamatan, perhatian, ingatan, daya pikir dan fantasi. Di dalam kemampuan belajar ini, sehingga perkembangan berpikir siswa menjadi ukuran. Siswa yang taraf perkembangan berpikirnya konkrit (nyata) tidak sama dengan siswa yang berpikir secara operasional (berdasarkan pengamatan yang dikaitkan dengan kemampuan daya nalarnya).

c. Kondisi Jasmani dan Rohani Siswa

Siswa adalah makhluk yang terdiri dari kesatuan psikofisik. Jadi kondisi siswa yang mempengaruhi motivasi belajar disini berkaitan dengan kondisi fisik dan kondisi psikologis, tetapi biasanya guru lebih cepat melihat kondisi fisik, karena lebih jelas menunjukkan gejalanya dari pada kondisi psikologis.

\footnotetext{
${ }^{24}$ Hamzah B Uno. Teori..., h.33

${ }^{25}$ Dimyati dan Mudjiono. Belajar dan Pembelajaran. Jakarta: PT Rineke Cipta ,2006, h.89-92

${ }^{26}$ Suciati dan Prasetya Irawan. Teori Belajar dan Motivasi. Jakarta: PAUPPAI Universitas
} Terbuka, 2001, h. 35 
Misalnya siswa yang kelihatan lesu, mengantuk mungkin juga karena malam harinya bergadang atau juga sakit.

d. Kondisi Lingkungan Kelas.

Kondisi lingkungan merupakan unsur-unsur yang datangnya dari luar diri siswa. Lingkungan siswa sebagaimana juga lingkungan individu pada umumnya ada tiga yaitu lingkungan keluarga, sekolah dan masyarakat. Jadi unsur-unsur yang mendukung atau menghambat kondisi lingkungan berasal dari ketiga unsur tersebut. Hal ini dapat dilakukan misalnya dengan cara guru harus berusaha mengelola kelas, menciptakan suasana belajar yang menyenangkan, menampilkan diri secara menarik dalam rangka membantu siswa termotivasi dalam belajar.

e. Unsur-unsur Dinamis Belajar

Unsur-unsur dinamis dalam belajar adalah unsur-unsur yang keberadaannya dalam proses belajar yang tidak stabil, kadang lemah dan bahkan hilang sama sekali.

f. Upaya Guru Membelajarkan Siswa

Upaya yang dimaksud disini adalah bagaimana guru mempersiapkan diri dalam membelajarkan siswa mulai dari penguasaan materi, cara menyampaikannya, menarik perhatian siswa.

Terkait dengan hal di atas, maka dibutuhkan teknik-teknik belajar. Seperti telah diketahui bahwa motivasi belajar selain berasal dari dalam diri siswa sendiri dapat juga berasal dari luar dirinya, dalam hal ini lingkungan dimana siswa itu sering berinteraksi yaitu; lingkungan rumah, sekolah dan teman-teman sepermainan. Apabila dari ketiga unsur lingkungan yang merupakan jenis motivasi ekstrinsik itu tidak mendukung motivasi intrinsik-nya maka lambat laun motivasi belajar siswa akan hilang. Oleh karena itu teknik-teknik ataupun caracara dalam mempertahankan bahkan meningkatkan motivasi belajar bagi para pelajar harus dilakukan.

Teknik-teknik tersebut menurut Hamzah $\mathrm{Uno}^{27}$ antara lain: a) Pernyataan penghargaan secara verbal, b) Menggunakan nilai ulangan sebagai pemacu keberhasilan, c) Menimbulkan rasa ingin tahu, d)Memunculkan sesuatu yang tidak diduga oleh siswa, e)Menjadikan tahap dini dalam belajar mudah bagi siswa, f) Menggunakan materi yang dikenal siswa sebagai contoh dalam belajar, g) Gunakan kaitan yang unik dan tak terduga untuk menerapkan suatu konsep dan prinsip yang telah dipahami, h)Menuntut siswa untuk menggunakan hal-hal yang telah dipelajari, i) Menggunakan simulasi dan permainan, j) Memberi kesempatan kepada siswa untuk memperlihatkan kemahirannya di depan umum, k) Mengurangi akibat yang tidak menyenangkan dan keterlibatan siswa dalam kegiatan belajar, 1)Memahami iklim sosial dalam sekolah, m) Memanfaatkan kewibawaan guru secara tepat, n)Memperpadukan motif-motif 
yang kuat, o) Memperjelas tujuan belajar yang hendak dicapai, p)Merumuskan tujuan-tujuan sementara, q) Memberitahukan hasil kerja yang telah dicapai, r) Membuat suasana persaingan yang sehat di antara para siswa, $s$ ) Mengembangkan persaingan dengan diri sendiri, dan t) Memberikan contoh yang positif.

Sedangkan yang dimaksud dengan kecerdasan emosional atau Emotional Intelligence (EQ), pada awalnya dicetuskan pada tahun 1990 oleh psikolog Peter Salovey dari Universitas Harvard dan John Mayer dari Universitas New Hampshire untuk menjelaskan kualitas emosional yang penting bagi keberhasilan kehidupan. Dalam perkembangan selanjutnya, berkat Daniel Goleman, kecerdasan emosional menjadi semakin populer lewat salah satu karyanya Emotional Intelligence: Why It Can Matter More than IQ.

Patton juga mengungkapkan bahwa kecerdasan emosional merupakan kemampuan untuk mengetahui emosi secara efektif agar berhasil dalam mencapai tujuan dan membangun hubungan yang produktif. Sementara Reuven Bar-On, salah seorang pakar psikologi, mendefinisikan kecerdasan emosional sebagai seperangkat kemampuan pribadi, emosional, dan sosial yang mempengaruhi kemampuan pribadi seseorang dalam mengatasi tuntutan dan beban lingkungan. ${ }^{28}$ Menurutnya, kecerdasan mosional adalah kumpulan keterampilan seperti optimisme, eksibilitas, pengelolaan stres dan kemampuan dalam berhubungan dengan orang lain. ${ }^{29}$

Gardner ${ }^{30}$, memandang kecerdasan manusia tidak hanya berdasarkan skor tes standar semata namun kecerdasan sebagai kemampuan untuk menyelesaikan masalah yang terjadi dalam kehidupan manusia, sebagai kemampuan untuk menghasilkan persoalan-persoalan baru untuk diselesaikan, dan sebagai kemampuan untuk menciptakan sesuatu atau menawarkan jasa yang akan menimbulkan penghargaan dalam budaya seseorang. Torndike dalam Sunar ${ }^{31}$ membagi kecerdasan manusia menjadi tiga, yaitu; 1)Kecerdasan abstrak, yaitu kemampuan memahami simbol matematis atau bahasa.2)Kecerdasan konkrit, yaitu kemampuan memahami objek nyata. 3)Kecerdasan sosial, yaitu kemampuan untuk memahami dan mengelola hubungan manusia yang dikatakan menjadi akar istilah kecerdasan emosional.

Sementara menurut Goleman emosi sangat berperan penting dalam keberhasilan seseorang baik di tempat kerja, tempat belajar, rumah dan hubungan antar sesama maupun diri sendiri. Emosi adalah kekuatan tanpa batas

${ }^{28}$ Daniel Goleman. Working With Emotional Intelligence. Jakarta: PT. Gramedia Pustaka Utama, 2000, h.180.

${ }^{29}$ Jeanne Anne. Bukan Seberapa Cerdas Diri Anda Tetapi Bagaimana Anda Cerdas. Batam: Interaksara, 2004, h.18.

${ }^{30}$ Hamzah B. Uno, Orientasi Baru dalam Psikologi Pembelajaran, Jakarta: Bumi. Aksara, 2012, h.60

${ }^{31}$ P. Sunar, Edisi Lengkap Tes IQ, EQ, dan SQ. Cet. I, Jakarta: FlashBooks, 2010, h.159 
yang dapat dimanfaatkan untuk meraih sukses dalam hidup ${ }^{32}$. Kecerdasan emosional atau biasa dikenal dengan EQ (Emotional Quotient) adalah kemampuan seseorang untuk menerima, menilai, mengelola, serta mengontrol emosi dirinya dan orang lain di sekitarnya. Dari beberapa pengertian tersebut dapat dipahami bahwa kecerdasan emosional berkenaan dengan hati dan kepedulian antar sesama manusia, makhluk lain, dan lingkungan sekitar.

Horwad Gardner mengungkapkan bahwa terdapat lima pokok utama dari kecerdasan emosional seseorang yakni mampu menyadari dan mengelola emosi diri sendiri, memiliki kepekaan terhadap emosi orang lain, mampu merespon dan bernegosiasi dengan orang lain secara emosional, serta dapat menggunakan emosi sebagai alat untuk memotivasi diri. ${ }^{33}$

Steven J. Stein dan Howard E. Book membagi kecerdasan emosional ke dalam lima area atau ranah yaitu:

a. Ranah Intrapribadi, ranah ini terkait dengan kemampuan kita untuk mengenal dan mengendalikan diri sendiri. Ranah Intrapribadi meliputi kesadaran diri, sikap asertif, kemandirian, penghargaan diri dan aktualisasi diri.

b. Ranah antarpribadi, yaitu berkaitan dengan ketrampilan bergaul yang kita miliki, kemampuan kita berinteraksi dan bergaul baik dengan orang lain. Ranah antarpribadi meliputi empati, tanggungjawab sosial, hubungan antar pribadi.

c. Ranah penyesuaian diri, berkaitan dengan kemampuan untuk bersikap lentur dan realistis, dan untuk memecahkan aneka masalah yang muncul. Ranah penyesuaian diri meliputi uji realitas, sikap fleksibel, dan pemecahan masalah.

d. Ranah pengendalian stres, ranah ini terkait dengan kemampuan kita untuk tahan menghadapi stres dan mengendalikan impuls. Ranah pengendalian stres meliputi ketahanan menanggung stres, pengendalian impuls.

e. Ranah suasana hati umum, yaitu berkaitan dengan pandangan kita tentang kehidupan, kemampuan kita bergembira sendiri dan dengan orang lain, serta keseluruhan rasa puas dan kecewa yang kita rasakan. Ranah suasana hati meliputi optimisme, kebahagiaan. ${ }^{34}$

Berdasarkan pernyataan di atas, dapat disimpulkan bahwa kecerdasan emosional merupakan suatu kemampuan untuk mengenali emosi diri, mengelola emosi diri, memotivasi diri, mengenali emosi orang lain dan kemampuan untuk membina hubungan dengan orang lain.

${ }^{32}$ Hamzah B. Uno, Orientasi Baru dalam Psikologi Pembelajaran, Jakarta: Bumi. Aksara, 2008, h.

${ }^{33}$ Hamzah B. Uno. Orientasi Baru..., h.120

${ }^{34}$ Steven J. Stein dan Howard E Book. Ledakan EQ: 15 Prinsip Dasar Emosional Meraih Sukses. terj. Trinanda Rainy Januarsari dan Yudi Murtanto, Bandung: Kaifa, 2002, h. 39-41 
Lalu agar berhasil dalam belajar, lingkungan menjadi salah satu faktor pendukung. Lingkungan belajar yang kondusif akan membantu siswa menyerap materi belajar dan memberikan daya dorong (motivasi) siswa untuk berkonsentrasi. Dengan menciptakan lingkungan belajar yang tepat, siswa dapat mencapai hasil yang lebih baik dan menikmati proses pembelajaran. Sebelum dibahas lebih jauh tentang lingkungan belajar, berikut diuraikan apa yang dimaksud dengan lingkungan menurut para ahli.

Lingkungan belajar dapat diartikan juga dengan lingkungan pendidikan. Lingkungan belajar adalah tempat terjadinya kegiatan belajar yang mendapatkan pengaruh dari luar terhadap keberlangsungan kegiatan tersebut.

Menurut Heimstra dalam Harjali ${ }^{35}$ mendefinisikan lingkungan belajar sebagai "Learning environment is all of the physical surrounding, psycological or emotional condition, and social or cultural influences affecting the growth and development of an adult engaged in an educational enterprise". (Lingkungan belajar adalah semua lingkungan fisik, kondisi psikologis, emosional, dan aspek sosial atau budaya yang mempengaruhi pertumbuhan dan perkembangan orang dewasa yang terlibat dalam bidang pendidikan). Pengertian secara sederhana dapat dirumuskan bahwa lingkungan belajar merupakan tempat atau suasana (keadaan) yang mempengaruhi proses perubahan tingkah laku siswa. ${ }^{36}$

Lingkungan berpengaruh dalam pemberian stimulus yang akan diterima individu atau lingkungan akan menimbulkan respons pada individu. Lingkunganpun berperan didalam individu saat menerima stimulus yang datang dari luar. Lingkungan yang merupakan sumber belajar memiliki pengaruh dalam proses pembelajaran. Lingkungan sekitar yang sengaja digunakan sebagai alat dalam proses pendidikan (pakaian, keadaan rumah, alat permainan, buku-buku, alat peraga, dan lain-lain) dinamakan sebagai lingkungan pendidikan ${ }^{37}$. Lingkungan belajar menjadi salah satu faktor yang mempengaruhi prestasi belajar. Lingkungan belajar seyogyanya mendapat prioritas dalam kegiatan belajar karena memberikan dampak yang besar terhadap proses dan hasil perilaku siswa, baik secara langsung maupun tidak langsung. Lingkungan belajar yang memungkinkan siswa untuk membuat pilihan-pilihan mendorong siswa untuk terlibat secara fisik, emosional dan mental dalam proses pembelajaran sehingga dapat mengarah pada kegiatan kreatif. Lingkungan tidak dapat dipisahkan dari kehidupan manusia karena memiliki hubungan yang koheren antara keduanya di mana lingkungan dapat mempengaruhi manusia dan sebaliknya. Demikian pula, dalam proses belajar, lingkungan adalah sumber belajar yang berpengaruh dalam proses belajar dan 2019, h. 24

${ }^{35}$ Harjali. Penataan Lingkungan Belajar: Strategi untuk Guru dan Sekolah. Malang: Seribu Bintang,

${ }^{36}$ Harjali. Penataan Lingkungan..., h. 24

${ }^{37}$ Hasbullah, Dasar-Dasar Ilmu Pendidikan, Jakarta: PT Rajagrafindo Persada, 2012, h. 33 
perkembangan anak. Fraser dalam Harjali ${ }^{38}$ mengemukakan bahwa setiap individu mempunyai genetis untuk menyesuaikan diri dengan lingkungannya dan mempunyai pola perilaku tertentu untuk menanggulangi masalah lingkungan.

Beberapa ahli menggolongkan lingkungan belajar menjadi beberapa bagian. Diantara para ahli yang dimaksud adalah:

a. Saroni ${ }^{39}$ membuat pengertian bahwa "lingkungan belajar" merupakan segala sesuatu yang berhubungan dengan tempat proses pembelajaran dilaksanakan". Lingkungan belajar menurutnya mencakup dua hal utama yaitu, lingkungan fisik dan lingkungan sosial. Lingkungan fisik adalah lingkungan yang ada di sekitar siswa, berupa sarana fisik, baik yang ada di dalam sekolah maupun di sekitar sekolah, termasuk masyarakat. Dalam hal ini lebih ditekankan pada lingkungan fisik dalam kelas, seperti alat atau media pembelajaran. Lingkungan fisik merupakan sumber kepuasan, keluhan, dan simbol atau perwujudan dari prestasi yang dalam. Lingkungan yang kurang mendukung pelaksanaan pembelajaran seperti kurangnya alatalat laboratorium, ruangan yang pengap, ventilasi yang kurang, rusaknya peralatan, hubungan yang kurang serasi antar siswa, penerangan yang kurang, prosedur dan tata kerja yang tidak jelas, ikut menyebabkan kinerja yang buruk. Kondisi sekolah atau kelas yang kurang memadai menyebabkan siswa akan bersikap acuh pada tugas-tugas belajarnya. Tidak adanya percikan motivasi untuk berkreasi menyebabkan produktivitas siswa menurun, akhirnya mereka akan mencari sekolah yang akan memberikan lingkungan belajar yang baik. Sementara lingkungan sosial berhubungan dengan pola interaksi antar personal yang ada di lingkungan sekolah secara umum. Kondisi pembelajaran yang kondusif hanya dapat dicapai jika interaksi sosial ini berlangsung dengan baik.

b. Muhibbin Syah ${ }^{40}$, ia membagi lingkungan hanya menjadi dua golongan besar yaitu lingkungan sosial dan non sosial. Lingkungan sosial menurutnya terdiri dari lingkungan sosial sekolah, lingkungan sosial siswa, dan lingkungan keluarga. Pembagian seperti ini hampir mirip dengan yang pertama, hanya saja peneliti menganggap pembagian ini lebih fleksibel, lebih sederhana dan lebih banyak cakupannya karena Muhibbin mengelompokkan segala sesuatu yang tidak berkaitan dengan sosial menjadi lingkungan nonsosial, semisal gedung sekolah, rumah tempat tinggal, alat-alat belajar, sumber belajar, keadaan cuaca, pencahayaan, waktu belajar yang digunakan siswa, dan lain-

\footnotetext{
${ }^{38}$ Harjali. Penataan Lingkungan..., h. 45

${ }^{39}$ Muhammad Saroni, Manajemen Sekolah: Kiat Menjadi Pendidik yang Kompeten, Yogyakarta: ArRuzz Media, 2006, h.82-83

${ }^{40}$ Muhibbin Syah, Psikologi Pendidikan dengan Pendekatan Baru, Bandung: Rosdakarya, 2011, h. 137.
} 
lain. Bukan seperti pendapat Saroni dimana lingkungan fisik yang terbatas cakupannya.

c. Nana Syaodih ${ }^{41}$ mempunyai pendapat yang hampir mirip tapi agak diperlebar dimana ia mengemukakan bahwa lingkungan pendidikan lebih luas lagi yaitu selain lingkungan fisik dan lingkungan sosial, terdapat pula lingkungan intelektual, dan lingkungan lainnya. Lingkungan fisik yang dimaksud itu adalah lingkungan alam dan lingkungan buatan manusia yang terkadang memberikan dukungan dan hambatan dalam berlangsungnya proses pendidikan. Sedangkan lingkungan sosial merupakan lingkungan pergaulan antar manusia, pergaulan antar pendidik dengan peserta didik serta orangorang lainnya yang terlibat dalam interaksi pendidikan. Kemudian apa yang dimaksud dengan lingkungan intelektual?. Menurut Syaodih, lingkungan intektual itu merupakan piranti lunak yang sangat berkembang saat ini, seperti sistem program-progran pengajaran, media, dan sumber media. Ternyata oleh Syaodih nilai kemasyarakatan, ekonomi, sosial, politik, dan estetika dimasukkan ke dalam golongan lingkungan lainnya.

d. Pendapat Slameto ${ }^{42}$ nampaknya lebih mudah dimengerti, disamping lebih umum dan lebih mudah diingat. Apa itu?, menurutnya lingkungan belajar adalah lingkungan keluarga, lingkungan sekolah, dan lingkungan masyarakat.

1) Lingkungan Keluarga, merupakan lingkungan pertama yang ditemui oleh individu dan juga tempat pertama yang mempengaruhi karakter individu tersebut. Adapun yang termasuk lingkungan belajar dari keluarga adalah cara orang tua mendidik, relasi antara anggota keluarga, suasana rumah, keadaan ekonomi keluarga, pengertian orang tua, dan latar belakang kebudayaan. Di sini, nilai-nilai kepatuhan dalam suatu hubungan kepribadian dan saling menghargai menjadi sangat berarti. Dalam hal ini, keluarga memainkan peran dan tanggung jawab penting dalam pendidikan anak. Orang tua di lingkungan ini menjadi guru dan anakanak menjadi siswa. Saat pertama kali dilahirkan, seorang anak dalam keadaan fitrah dan berhati suci lagi bersih.

2) Lingkungan Sekolah, yaitu mencakup metode mengajar, kurikulum, relasi guru dengan siswa, relasi siswa dengan siswa, disiplin sekolah, alat pelajaran, waktu sekolah, keadaan gedung, metode belajar, dan tugas rumah. Lingkungan sekolah merupakan lingkungan tempat peserta didik menyerap nilai-nilai akademik termasuk bersosialisasi dengan guru dan teman sekolah.

3) Lingkungan Masyarakat, lingkungan yang juga mempengaruhi siswa belajar yang meliputi kegiatan siswa dalam masyarakat, media sosial, 2004, h. 5

${ }^{41}$ Nana Syaodih Sukmadinata, Landasan Psikologi Proses Pendidikan, Bandung: Rosdakarya, 42Slameto, Belajar dan Faktor-Faktor Yang Mempengaruhinya, Jakarta: Rineke Cipta, 2015, h.60 
teman bergaul, dan bentuk kehidupan masyarakat. Lingkungan masyarakat memainkan peran penting dalam pendidikan, bagaimanapun peserta didik hidup di lingkungan masyarakat sehingga pola dan gaya perilakunya dipengaruhi oleh lingkungan masyarakat. Peran masyarakat sangat penting karena anak-anak tinggal di lingkungan untuk waktu yang lama. Oleh karena itu masyarakat harus dilibatkan dalam proses pendidikan dan mentransfernya ke lingkungan masyarakat agar pendidikan tidak terbatas pada sekolah, dengan demikian prinsip long life education akan tercipta. Lingkungan masyarakat hendaknya digunakan sebagai tempat untuk mendapatkan pengetahuan. Masyarakat dapat memberikan akses ke pendidikan non-formal, seperti pesantren, kursus, dan lain-lain yang dapat menumbuhkan dan mengembangkan potensi warganya, terutama anak-anak.

Tentu saja, saat proses pembelajaran berlangsung siswa memerlukan lingkungan yang nyaman, tenang, tidak berisik, dan tentunya harus mendukung untuk belajar. Lingkungan yang kondusif diperlukan agar siswa dapat berkonsentrasi dengan baik sehingga dapat dengan mudah menyerap pelajaran. Lingkungan yang tidak menguntungkan mengganggu proses belajar, sehingga akan menghambat siswa menyerap pelajaran.

\section{B. METODE}

Metode yang digunakan dalam penelitian ini adalah dengan menggunakan metode survey dengan pendekatan korelasional. Metode survey digunakan dg pertimbangan-pertimbangan penelitian dilakukan untuk mendapatkan data setiap variabel masalah penelitian dari tempat tertentu yang alamiah dengan alat pengumpul data berbentuk angket (quesioner), test dan wawancara terstruktur dan berdasarkan pandangan dari sumber data, bukan dari peneliti.

\section{PEMBAHASAN}

\section{Pengaruh Kecerdasan Emosional $\left(X_{1}\right)$ terhadap Motivasi Belajar Siswa Kelas XI SMA Negeri 3 Tangsel.}

Terlihat ada pengaruh signifikan secara parsial kecerdasan emosional terhadap hasil motivasi belajar siswa SMA Negeri 3 Tangsel yang terbukti thitung $>\mathrm{t}$ tabel $(3.048>1,655)$. Dengan demikian, pengujian menunjukkan Ho ditolak dan $\mathrm{H}_{1}$ diterima. Oleh karena itu, dapat disimpulkan dari hasil tersebut yang memperlihatkan bahwa variabel kecerdasan emosional secara sendiri-sendiri (parsial) berpengaruh terhadap motivasi belajar siswa.

Berdasarkan analisis tersebut bahwa kecerdasan emosional merupakan salah satu factor penentu yang mempengaruhi Motivasi Belajar siswa. Selanjutnya akan diuraikan hasil uji hipotesis beserta teori-teori yang telah 
diungkapkan sebelumnya.

\section{Pengaruh Lingkungan Belajar $\left(X_{2}\right)$ terhadap Motivasi Belajar Siswa Kelas XI SMA Negeri 3 Tangsel.}

Hasil penelitian menunjukkan bahwa ada pengaruh positif lingkungan belajar secara parsial terhadap motivasi belajar siswa SMA Negeri 3 Tangsel ditinjau dari nilai thitung yang lebih besar dari nilai tabel $(4,043>1,655)$. Dengan demikian, pengujian menunjukkan $\mathrm{Ho}$ ditolak dan $\mathrm{H}_{1}$ diterima. Oleh karena itu, dapat disimpulkan dari hasil tersebut bahwa variabel lingkungan belajar secara sendiri-sendiri (parsial) berpengaruh terhadap motivasi belajar siswa. Deskripsi lingkungan belajar siswa hasil penelitian ini dikategorikan baik $(59,7 \%)$. Hasil penelitian ini sejalan dengan teori-teori yang telah dikemukakan sebelumnya.

Pertama; penelitian ini sesuai dengan pendapat Patterson dan Loeber (1984) seperti yang dikutip oleh Syah ${ }^{43}$, lingkungan sosial yang lebih banyak mempengaruhi kegiatan belajar siswa ialah orang tua dan keluarga siswa itu sendiri. Hal tersebut tercermin dari sifat-sifat orang tua dan ketaatan kepada norma keluarga. Lingkungan keluarga sangat penting dalam mempengaruhi motivasi belajar siswa sehingga lingkungan keluarga yang baik dapat meningkatkan motivasi belajar siswa.

Kedua; lingkungan belajar terutama lingkungan keluarga, merupakan lingkungan pertama yang ditemui oleh individu dan juga tempat pertama yang mempengaruhi karakter individu tersebut. Adapun yang termasuk lingkungan belajar dari keluarga adalah cara orang tua mendidik, relasi antara anggota keluarga, suasana rumah, keadaan ekonomi keluarga, pengertian orang tua, dan latar belakang kebudayaan. Di sini, nilai-nilai kepatuhan dalam suatu hubungan kepribadian dan saling menghargai menjadi sangat berarti. Dalam hal ini, keluarga memainkan peran dan tanggung jawab penting dalam pendidikan anak. Orang tua di lingkungan ini menjadi guru dan anak-anak menjadi siswa. Saat pertama kali dilahirkan, seorang anak dalam keadaan fitrah dan berhati suci lagi bersih. Selanjutnya, orang tua yang memainkan peran penting dalam perkembangan masa depan anak untuk menjaga fitrah dan kesucian hatinya, ataukah malah merusak dan mencemarinya. Sebagaimana hadits Nabi Muhammad SAW tentang fitrah anak yang baru lahir

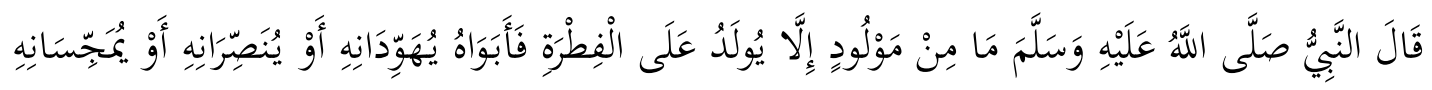

h. 138.

43Muhibbin Syah, Psikologi Pendidikan dengan Pendekatan Baru, Bandung: Rosdakarya, 2011, 
Nabi bersabda, "Tidak ada anak yang dilahirkan, kecuali dilahirkan atas kesucian. Dua orang tuanyalah yang menjadikannya Yahudi, Nasrani, atau Majusi (HR. al-Bukhari \& Muslim)

Jadi orang tua adalah motivator yang paling diharapkan dalam mengembangkan kepribadian seorang anak.

\section{Pengaruh Kecerdasan Emosional $\left(X_{1}\right)$ dan Lingkungan Belajar $\left(X_{2}\right)$ secara simultan terhadap Motivasi Belajar (Y) Siswa Kelas XI SMA Negeri 3 Tangsel.}

Hasil analisis dapat membuktikan bahwa kecerdasan emosional, dan lingkungan belajar secara simultan berpengaruh terhadap motivasi belajar, siswa kelas XI SMA Negeri 3 Tangsel pada. Pernyataan ini dibuktikan dengan hasil perhitungan yang menunjukkan bahwa taraf sig. $F$ yang lebih kecil dari 0,05 yaitu sebesar 0,000, dan Fhitung $(14,060)$ yang lebih besar dari $F_{\text {tabel }}(3,060)$. Pengaruh ini dikarenakan adanya simbiosis antara kecerdasan emosional dan lingkungan belajar siswa yang baik untuk menghasilkan suatu tujuan yaitu motivasi belajar. Motivasi belajar dan kecerdasan emosional yang baik juga dapat dibentuk melalui lingkungan belajar yang baik. Sehingga jika lingkungan keluarga siswa baik maka akan dapat menciptakan motivasi belajar dan kecerdasan emosional anak dengan baik pula. Untuk menciptakan motivasi belajar dan kecerdasan emosional yang baik pada siswa maka perlu adanya peran lingkungan keluarga yaitu kontrol dari orang tua dalam kehidupan sehari-hari siswa baik pada hal yang berhubungan dengan proses pembelajaran maupun yang bukan proses pembelajaran di sekolah selain lingkungan sekolah yang kondusif. Dengan kecerdasi ssional dan lingkungan belajar yang baik maka akan dapat berdam da motivasi belajar yang baik bagi siswa.

\section{KESIMPULAN}

Berdasarkan penjabaran hasil analisis dan pembahasan, maka secara garis besar dapat ditarik kesimpulan bahwa:

1. Ada pengaruh positif dan signifikan kecerdasan emosional sebesar $6,1 \%$ terhadap motivasi belajar siswa kelas XI SMA Negeri 3 Tangsel, dimana semakin tinggi tingkat kecerdasan emosional, maka semkin tinggi pula motivasi belajar siswa.

2. Ada pengaruh positif dan signifikan lingkungan belajar sebesar $10,3 \%$ terhadap motivasi belajar siswa kelas XI SMA Negeri 3 Tangsel, dimana semakin baik kondisi lingkungan belajar siswa, maka semakin tinggi pula motivasi belajar siswa..

3. Ada pengaruh positif dan signifikan kecerdasan emosional $\left(X_{1}\right)$ dan Lingkungan Belajar ( $\left.\mathrm{X}_{2}\right) \quad 16,6 \%$ yang secara bersama-sama (simultan) 
mempengaruhi terhadap motivasi belajar (Y) kelas XI siswa SMA Negeri 3 Tangerang Selatan.

\section{DAFTAR PUSTAKA}

A.M, Sardiman. Interaksi dan Motivasi Belajar Mengajar. Jakarta: Rajawali, 2018.

Anne, Jeanne. Bukan Seberapa Cerdas Diri Anda Tetapi Bagaimana Anda Cerdas. Batam: Interaksara, 2004.

Dimyati dan Mudjiono. Belajar dan Pembelajaran. Jakarta: PT Rineke Cipta, 2006

Goleman, Daniel. Kecerdasan Emosional (terjemahan oleh T. Hermaya). Jakarta: PT. Gramedia Pustaka Utama, cetakan ke-24, 2018.

------. Working With Emotional Intelligence (terjemahan oleh T. Hermaya). Jakarta: PT. Gramedia Pustaka Utama, 2000, h.180.

Gottman, John. Kiat-kiat Membesarkan Anak yang Memiliki Kecerdasan Emosional (terjemahan). Jakarta: PT Gramedia Pustaka Utama, 2001.

Hamalik, Oemar. Prosedur Belajar Mengajar. Jakarta: Bumi Aksara, 2003.

Harjali. Penataan Lingkungan Belajar: Strategi untuk Guru dan Sekolah. Malang: Seribu Bintang, 2019.

Hasbullah, Dasar-Dasar Ilmu Pendidikan, Jakarta: PT Rajagrafindo Persada, 2012.

Husamah, dkk. Belajar dan Pembelajaran. Malang: UMM Press, 2018.

Iskandar. Metodologi Penelitian Kualitatif. Jakarta: Gaung Persada Press, 2009.

Jalaluddin \& Jalaluddin As-Suyuthi. Tafsir Jalalain. Terjemahan Bahrun Abu Bakar, Jakarta: Sinar Baru Algensindo, 2008.

Nashar, H. Peranan Motivasi dan Kemampuan awal dalam kegiatan Pembelajaran. Jakarta: Delia Press, 2004.

Nursalam dan Ferry Efendi. Pendidikan dalam Keperawatan. Jakarta: Salemba Medika, 2008.

Saroni, Muhammad. Manajemen Sekolah: Kiat Menjadi Pendidik yang Kompeten, Yogyakarta: Ar-Ruzz Media, 2006.

Shihab, Quraish. Tafsīr Al-Mishbah, Pesan, Kesan dan Keserasian al-Qur'ān. Vol.3, Jakarta: Lentera Hati, 2002.

Slameto. Belajar Dan Faktor-Faktor Yang Mempengaruhinya. Cet.6, Jakarta: PT Rineka Cipta, 2015.

Stein, Steven J. dan Howard E Book. Ledakan EQ: 15 Prinsip Dasar Emosional Meraih Sukses. terj. Trinanda Rainy Januarsari dan Yudi Murtanto, Bandung: Kaifa, 2002. 
JURNAL PENDIDIKAN ISLAM, VOL. 1, NO. 1 TAHUN 2019

MAGISTER MANAJEMEN PENDIDIKAN ISLAM INSTITUT PTIQ JAKARTA

Suciati dan Prasetya Irawan. Teori Belajar dan Motivasi. Jakarta: PAUPPAI Universitas Terbuka, 2001.

Sukmadinata, Nana Syaodih. Landasan Psikologi Proses Pendidikan, Bandung: Rosdakarya, 2004.

Sunar, P. Edisi Lengkap Tes IQ, EQ, dan SQ. Cet. I, Jakarta: FlashBooks, 2010.

Syah, Muhibbin. Psikologi Pendidikan dengan Pendekatan Baru, Bandung: Rosdakarya, 2011.

Uno, Hamzah B. Orientasi Baru dalam Psikologi Pembelajaran, Jakarta: Bumi. Aksara, 2012.

------. Teori Motivasi dan Pengukurannya. Jakarta: PT Bumi Aksara, 2011.

Widodo, Alex Tri Kantjono. Kecerdasan Emosi untuk Mencapai Puncak Prestasi. Jakarta: PT. Gramedia Pustaka Utama. Terjemahan: Working With Emotional Intelligence, Goleman, D, 1999. 